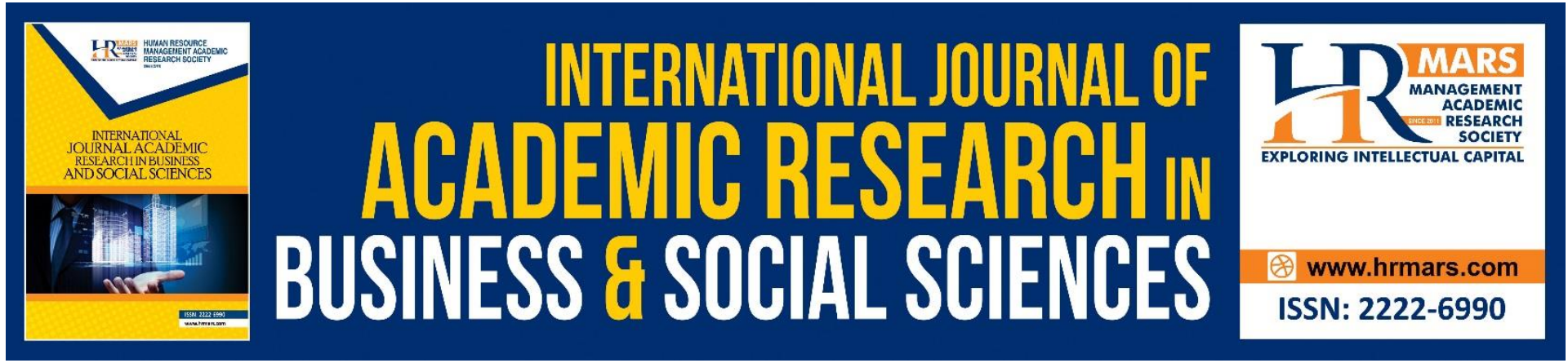

\title{
Driving Youth Participation in Agriculture: A Synopsis of the Influence of Existing Agricultural Policies in Selected Counties in Kenya
}

\author{
Musundi C. Laban, Wahome K. Anthony, Odula B. Elias
}

To Link this Article: http://dx.doi.org/10.6007/IJARBSS/v11-i9/10982

DOI:10.6007/IJARBSS/v11-i9/10982

Received: 14 July 2021, Revised: 16 August 2021, Accepted: 30 August 2021

Published Online: 18 September 2021

In-Text Citation: (Laban et al., 2021)

To Cite this Article: Laban, M. C., Anthony, W. K., \& Elias, O. B. (2021). Driving Youth Participation in Agriculture: A Synopsis of the Influence of Existing Agricultural Policies in Selected Counties in Kenya. International Journal of Academic Research in Business and Social Sciences, 11(9), 991-1015.

Copyright: (c) 2021 The Author(s)

Published by Human Resource Management Academic Research Society (www.hrmars.com) This article is published under the Creative Commons Attribution (CC BY 4.0) license. Anyone may reproduce, distribute, translate and create derivative works of this article (for both commercial and non-commercial purposes), subject to full attribution to the original publication and authors. The full terms of this license may be seen at: http://creativecommons.org/licences/by/4.0/legalcode

Vol. 11, No. 9, 2021, Pg. 991 - 1015

Full Terms \& Conditions of access and use can be found at http://hrmars.com/index.php/pages/detail/publication-ethics 


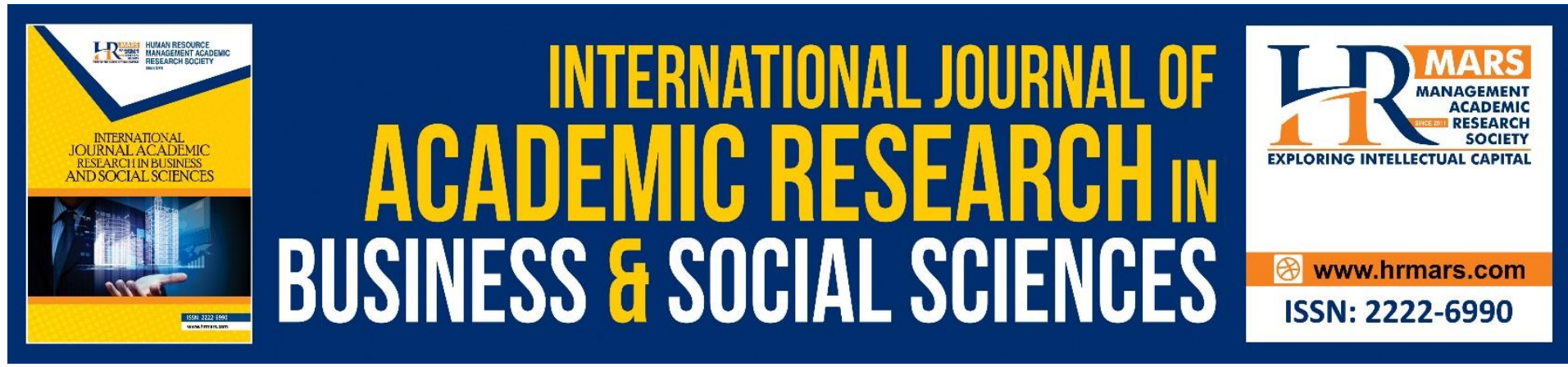

\title{
Driving Youth Participation in Agriculture: A Synopsis of the Influence of Existing Agricultural Policies in Selected Counties in Kenya
}

\author{
Musundi C. Laban \\ Kenya School of Government - Embu, Seniour Lecturer \\ Wahome K. Anthony \\ Kenya School of Government - Embu, Principal Lecturer \\ Email: antony.wahome@ksg.ac.ke \\ Odula B. Elias \\ Kenya School of Government - Embu, Lecturer \\ Email: elias.odula@ksg.ac.ke
}

\begin{abstract}
Agriculture is the backbone of Kenya's economy, contributing (24\%) of the GDP. The Agricultural Sector Development Strategy showed that the sector accounts for (65\%) of Kenya's total exports and provides more than (18\%) of formal employment, (70\%) of informal employment. It provides livelihood to $(80 \%)$ of the Kenyan population. The Government of Kenya is committed to reducing hunger and malnutrition. To end hunger, achieve food security, improve nutrition, and promote sustainable agriculture as specified in (SDG2), the Government launched the 'Big 4 Agenda'. These include strategies to build self-reliance, reduce chronic food insecurity. During the quarter under review, there was heightened Agricultural activity that significantly anchored the overall economic performance. The low response to National and County Governments incentives suggests that these efforts have not been met with buy-in of the Youth. The institutional, social, and infrastructural investments have not produced the expected in-flow of the Youth into the Agricultural sector. Under-investigated determinant like Agricultural Policies are perceived to influence Youth Participation. This study sought to explore the influence of these determinant on the dependent variable. Employing a descriptive survey design and inferential statistics as tools of analysis, with a sample size of 194 respondents drawn from (7) Kenyan Counties. A simple linear regression was applied, whereby the independent variable (Agricultural Policies) was regressed against the dependent variable (Participation of Youth in Agriculture). Agricultural Polices did have a statistically significant influence on Youth Participation. It emerged that there were no actively supportive policies on Youth Participation in Agriculture. No pricing policies; absence of Youth specific safeguard policies against competition among others. The study recommends that the National and County Governments through their respective
\end{abstract}


Agricultural authorities (Ministries/Departments) develop intervention strategies policies and services to pull Agricultural Oriented Youth through provision of kinds of capital and initiate the use of extension services.

Keywords: Determinants, Youth, Youth Participation in Agriculture, Agricultural Policies, Pull, Push

\section{Introduction}

On the occasion of launching the Big 4 Agenda in 2017 in Nairobi, His Excellency Uhuru Muigai Kenyatta the President of the Republic of Kenya indicated that he will be calling upon the research community composed of formal research institutions both public and private as well as academic institutions to make their contribution towards the realization of the agenda as well as address matters of Food security, improved nutrition, promote sustainable agriculture as per the sustainable development goal number two (SDG2) of the United Nations. That the named institutions would be draw from their vast reserves of cumulated data to drive the process and generate solutions and innovations. One other reserve they can draw from is the large population of the Youth in our country reported to be $75.1 \%$ or 35.7 million Kenyans. The vast number 32.7 million or $68.7 \%$ reside in the rural areas as per the population and household census undertaken by the Kenya National Bureau of Statistics in the year 2019.

\section{A Fresh Look at Agriculture}

At one time on the surface of the earth, there was no agriculture. The population was small and scattered and thus food needs were minimal. Hunting and gathering was sufficient to provide the needs and when the animals moved on and drier climes expanded, food sources had to be secured through domestication first of animals then of plants to feed the growing population and thus the beginning of civilization anchored on development of agriculture. This period is scientifically known as the Neolithic period. The population of the Human species continuous to grow, the climate on the other hand and the soils are challenging steady food supplies. This then calls for fresh perspective, to alter the narrative from the undifferentiated Agriculture, to one that can anchor multisectoral development including but not limited to its traditional source of food, but also get enmeshed in: food and non food processing; contract farming for such other products like silk worms; butterfly farming; breeding crustaceans like shrimps, cockroaches, snails; herbs; mushroom farming. Thus transforming Agriculture into a money making and entrepreneurship thereby attracting interest of the public and thus investors both public and private. This new perspective has the potential to create challenges and opportunities to: Aggregators, producers, processors, wholesalers, retailers and other players in the Agricultural supply and value chains. The soldiers to lead us to break fresh ground are the Youth of today thus the key task of having them board the bus to nirvana.

While the role of Agriculture 2012) in job and wealth creation for young people has been has been recognized, the link between the youth and agriculture has only been partially or insufficiently been developed and translated into public policy (Food, Agriculture and Natural Resource Policy Analysis Network (FANRPAN), It is imperative that youth be at the table as critical players deserving of special attention, support and follow up in order to harness their energy, talents and passion and a resource in solving food security challenges. The youth need to be looked as a part of the solution and contributors to decisions and policy processes of concern to Agricultural productivity. 


\section{Statement of the Research Problem}

The Country's long term plan, Vision 2030, envisages a strong contribution from Agriculture to make up the ten percent $(10 \%)$ annual growth rate. The anticipation is that the entire agricultural sector a large chunk of which is small scale in nature will be key stakeholders thus a need to transformation from subsistence to viable commercial enterprises. The Agriculture Sector Development Strategy recognizes the potential in the Youth contribution towards Agricultural Development (Ministry of Agriculture, Livestock and Fisheries, 2017). However it has been a challenge has been and continous to be that the Agricultural Sector has not been attractive to the Youth more so that the policies that drive the sector have not been dynamic in contextualising the Youth and their growing importance. Many a youth face constraints in gaining access to land, credit, training and new technology. They have limited or in most cases no direct access to the agriclutural sector especially across the agriculural value chain (farming, research, innovation, product development and market participation. This work seeks to evaluate the situation and seek a way forward.

\section{Research Objectives, Hypothesis and Conceptual Model}

The general objective was to examine the influence Agricultural Policies on Youth participation in Agriculture in Kenya.

\section{Specific Objectives}

The specific objectives of the study include:

a) To establish the influence of Agricultural policies on Youth participation in Agriculture;

b) To make recommendations on the review, practice and application of the existing Agricultural

\section{Research Hypothesis}

Here we show the relationship between the study variables and the reviewed literature. It is at this point that the conceptual framework is also agree to. The hypothesis explained and would be later tested.

Lead by the stated objectives, the following hypothesis was identified:

\section{HO: Agricultural policies do not have a significant influence on Youth Participation in Agriculture.}

\section{Conceptual Model}

The conceptual framework provides a unified way of looking at a: Problem, situation or phenomena understudy (Liehr \& Smith, 1999), moreover a conceptual framework is the result of gathered concepts to explain or predict an event or an understanding of a research phenomenon. It is used make distinctions and organize ideas (Trigueros, 2018). The relationship is represented in figure below. 
Figure 3.3.1 Conceptual Framework

Independent Variable
Dependent Variable

Key Influence (Agricultural Policies)

- Impact of current Policy Governing Youth Participation in Agriculture

- Motivational Pricing Policies for the Youth

- Policies that encourage Youth to take reasonable risk

- Youths market sway over Agricultural cooperatives to accept and Sell Youth Produce

- Youth that participate in Agriculture not cushioned from unforeseen losses

- Policy of providing subsidies cost to Youth

- Supporting Youths that have completed training in Agriculture course to start up

There are a two theories grounding this work

\section{Entrepreneurial Cognition Approach Theory}

The authors define this theory as: The knowledge structures, that people use to make assessments, judgements or decisions involving opportunity evaluation, venture creation and growth. This paper adopts the entrepreneural congnition approach (Mitchel, et al., 2003) to explain characteristics and perceptions. In developing this paper, we believe that it captures the essense of the theme which is to encourage the youth to adopt a different view to agriculture away from the low esteem posotion they display towards the very viable economic activity that is within there reach.

Mitchel and his team defines an entreprenuer firstly as a fundamental worker, engaged in the job of wealth creation. The entrepreneural congnition approach theory identifies the interaction of socio-demographic factors such as age, culture gender etc; knowledge (technical, tacit or formal) and perception (individual, economic or socio-cultural). The theory posits that each of the factors play a part in all career decisions that are made including commencement of entrepreneurial activity. There have been studies that have shown that the need to supplement formal income or gain additional source of money has been expereinced more frequently in large rather than in small households. Perception is a key tool that can be used to influence interest especially among the Youth who would be made to see that they can have career as entrepreneurs.

\section{The Push and Pull Theory}

JodyAnne Kirkwood is a well known proponent of the Push-Pull theory. She posits that people have different motivations for becoming entrepreneuers, which can be classified into Push characteristics personal or external. Unfortunately the push factors are often negative. Alternately there ate those factors that draw or pull. They may be perceived opportunities. It is said that enterprises started on the basis of the pull factor have more staying power in contrast to those stubled on via the push factors. 
Youth often face pressures and or impediments that either pull them in or push them off on matters to do with their participation in Agricultural activities. Thus a perfect demonstration of the push and pull theory (Kirkwood, 2009). Some of this pull and push factors include: availability of arable land, land inaccessibility, high cost of land, lack of financial support for carrying out Agricultural activities, lack of a market for produce, inadequate information on agricultural policies as well as delayed payment for agricultural produce.

\section{Literature Review}

In Kenya, the youth are those classified as being between the ages of 18 to 35 years (Kenya National Bureaue of Statistics, 2019). As key demographic, the youth are not fully engaged in productive economic activities thereby heavily burdening the society. Yet they have the potential of being catalyst for change if hannessed and mobilised, they can be the backbone to prosperity.

The Kenyan economy is heavily anchored by Agriculture and Agricultural production. The contribution of the Agricultural sector is massive to the wellbeing of the Country in general in terms of food and nutrition and large in particular when looked at as a contributor to the national income terms. The sector is by a large measure dominant contributor to the economy both directly and indirectly as calculated in gross domestic product (GDP) terms. What this means is that any shocks on Agriculture would have a significant knock on effect on the engine of growth in general terms and the economy of the country in particular. There is a dawning realization that this engine while sputtering along, will slow down and eventually stop as a result of lack of renewal by injecting the youth. The youth are simply not attracted to the sector, the implication is that it is largely run and managed by an aging citizens. In Kenya the average age of a farmer is 60 . This individual is steeped in his/her ways and methods and often not open to new ideas and has a lot of trust in the tried and tested methods and practices. An argument by Gitau (Gitau, 2021) to the extent that agricultural activity will decline in the worst case scenario or be compromised if the young farmers do not replace the old generation makes a whole lot of sense. The argument continuous that the younger farmers have potential to learn new methods and practices that would overcome constraints to agricultural development such as control of pests, genetic improvement application of new methods and approaches to agriculture, use of artificial intelligence, big data among others. This fact is not unique to Kenya, in Malaysia the ninth development plan of the country as published in 2006 showed many young people left the Agricultural sector the third largest contributor to the country's economy after manufacturing and the service sector to elderly workers. A quick survey determined that many of the youths left the small scale farming of their parents among other reasons lack of interest, the lure of other attractions in the industrial sectors found mainly in the urban setting in contrast to the volatility of the agricultural sector dominant in the rural areas.

In order to feed Africa's rapidly growing and urbanizing population, the continents booming numbers of young people need to see agriculture as an attractive business choice enabled by technology. The growth of mobile phone use and digital innovation is a smart avenue to incentivize Africa's Youth to get involved along the food value chain; from production, aggregation to processing and marketing. Judicious use of such tools. As a matter of fact, the Youth are amenable to cutting edge technology. They can easily adopt to artificial intelligence (Al) in agriculture, application of big data, advanced analytics and machine learning to bring centuries old farming knowledge into the modern age, allowing optimization of crop yields 
and mitigating effects of climate change through methodologies like smart irrigation, precision farming

Most startups are youth owned or led therefore in need of an enabling policy environment, for instance it is widely appreciated that conventional banks do not fund startups. With this hindsight then it is critical to drive or guide the creative energy towards Agricultural production. A number of Programmes continent wide have been developed to try and achieve this goal. They include the Youth in Agriculture Program (YiAP) in Ghana

The relatively strong evidence around the research-technology- productivity nexus and issues around access to land suggest that they should continue to be a central focus, even though they cannot (and should not) be framed or justified as a 'Youth-specific' policy or program focus. In our view, it would be ill-judged to prioritize Youth-specific measures when these large structural issues persist. Until and unless the structural constraints are addressed, it is probably misguided to focus on how to change young people's aspirations and, or mindset in relation to Agriculture.

There is much heavy lifting to be done before the Agricultural sector can offer fulfilling and rewarding employment to significant numbers of young people, and no one should be fooled about the effort or the time this will take. It will be important to reflect on whether, how and in what situations the EU's strong orientation toward economic growth, market-based approaches and broadly applicable principles and frameworks are appropriate in relation to the structural transformation agenda. It is also important to consider the implications of the strong market-based orientation of policy and programs for the EU's commitment to rights, including the right to food and the right to education (Petersen, 2014).

Through the Agriculture Sector Development Strategy (ASDS) programme, the Government of Kenya guides the policies for the sector whose overiding goal is to achieve a progressive reduction in unemployement and poverty (Land Portal Foundation, 2021)which is actaully a bane for the youth since they form the largest percentage of those classified as such.

\section{Impact of current Agricultural Policies Governing Youth Participation in Agriculture}

Here is a snapshot preview of current policies for the Agricultural sector as depicted from the Ministry of Agriculture Livestock, Fisheries and Cooperatives website (www.kilimo.go.ke/ministry-policies/) Roots-and-Tubers crop strategy 2019 - 2022; under this strategy a telling observation is made on page 30. "in most communities' women and Youth do not own properties that could be used for collateral", worse still, "since they do not own properties, they are not considered during groups' leadership positions" (Ministry of Agriculture, Livestock, Fisheries and Cooperatives, 2019), in short they have no seat at the table and thus no part of the Policy process. Agricultural Reforms - Revitalisation of the Tea subsector- Executive Order No. 3 of 2021, nothing in here on Youth participation. National Rice Development Strategy - 2 (2019 - 2030) (Rice Promotion Programme, 2020) Here the youth are prominent in provision of labour and have neither policy roles nor managerial roles. These are just but a snapshot of the place of Youth in our current policy set up, thus not really endearing to them as active and serious participants, they are rather fringe players.

The challenge is to focus the mindset of youth towards Agriculture and agricultural practices and production. The problem here lies squarely with the overreliance of the policy makers on common knowledge to develop and argue policy alternatives meant to respond to the issue of youth and agriculture. Overall majority of existing policies may not be necessarily youth focused, therefore not a springboard for appropriate response, many of these are commonly at odds with the youths own imperatives, aspirations, strategies and activities (Food, 
Agriculture and Natural Resource Policy Analysis Network (FANRPAN), 2012). Much effort is required before the Agricultural sector can offer according to a majority of the Youth a fulfilling and rewarding opportunities for young people including employment, not discounting for the time and energy put into it.

\section{Policies that encourage Youth to take reasonable risk}

In Kenya and in most African Countries, there are institutions and mechanism overseeing engagement and funding of youth activities and initiatives. They include National Youth Councils, Youth Enterprise development funds, ministries and departments exclusively handling youth affairs as it happens in the National and County government level. As a matter of fact, there is also the Youth Development fund at the NEPAD level. If this mechanisms function optimally, they would serve as institutions through which youths would meaningfully engage in policy processes. The sponsoring entities would therefore take the opportunity to guide the youth towards a productive course even as the youth hold the driving seat. The findings therefore clearly indicate the gap between the intent of the Policies as stated by various institutions and the actual feel by the concerned parties in this case the Youth. Who say they have yet to experience the impact of the institutions and thus feel like they have been left to their own devices even as the institutions put in place exist. The fact then limits the risk appetite for the Youth and it becomes a push factor thus discouraging the Youth from participating actively in Agricultural activities

\section{Supporting Youths who Complete Training in Agriculture to Start Up}

Incidentally in Kenya training in Agriculture begins in Primary School. The Syllabus at primary school level has agriculture as an integral part of the curriculum. The challenge has been that where as a while ago it was practical, currently it is much more theory. Thus there is an opportunity here that needs to be harnessed, first, the Ministries of Education and that of Agriculture cooperate on the curricula development for Agriculture. Secondly beyond the curricula, they coordinate on reviving the Agriculture clubs (formerly known as the 4K clubs) at the basic education level as well as the farmers clubs at secondary level. They can also rope in the Agricultural Society of Kenya who have the ASK shows programs throughout the country. These clubs are viable vehicles for knowledge, advice, skills and technology sharing as well as foundations for aggregation as well as growth and development of social capital communities of trust (cooperatives, unions, consortia etc), as well as career guidance. (Gitau \& Goris, 2016)

\section{Summary of Literature Review}

Having looked at a cross section of some of the Agricultural policies in the Country as enumerated above namely: Impact of current policies that governing Youth participation in practice of Agriculture; Supporting policies for Youths that manage their risk exposure; support Startups for Youth that complete training in Agriculture seem to indicate a subtle neglect if not a complete abandonment of the Youth. Yet governments are quite aware that the active farmers are aging and that urgent intervention is critical to prepare the next generation of farmers. This then for intervention mechanisms to reverse the slide. The researchers have picked on trying to encourage the Youth and show them that there is a career open to them in Agriculture by use of the Entrepreneurial Cognition Approach Theory. These theory's aim is to show the youth that it is within their power to create wealth and opportunities which are therefore their taking in Agriculture. That theory along with the Push 
and Pull theory would aim at consolidating to the effect that in the push situation, where it looks like all one has are lemons, the opportunity presented is to make lemonade, thus turn the push into a pull. Make use of the general educated youth to make use of technological tools that would take a shorter period to familiarize with given their level of education to Agriprenuers from hydroponic farming which does not need farm land that due to their youth have no tenure to butterfly farming.

\section{Research Methodology}

The purpose was to investigate the influence of the Agricultural policies on Youth participation in Agriculture. However, this investigation was undertaken in seven subnational entities of the republic of Kenya known as Counties. They were: Embu, Isiolo, Kirinyaga, Kitui, Murang'a, Nyeri and Tharaka Nithi. The selected counties have active Agricultural sectors that range from crop farming both commercial and subsistence to pastoralism, rain fed agriculture to irrigation and they perverted several Agro climatic zones. Though this Counties surround the Mount Kenya Region, they would form a good representative sample when it comes to Youth representation in Kenya, secondly they were chosen due to proximity to the researcher. For data collection, the researchers used a questionnaire to generate data conducive for the purpose of the assignment at hand (Kabir, 2016). It had open and close ended questions. The close ended questions made use of a five point Likert scale where respondents completed the form according to their level of agreement with the statements.

A descriptive research design was applied for this work. This method fundamental describes a situation (Jackson, 2009). Applying the design, means and percentages were put to use and presented.

Inferential statistics were then applied in analyzing the data. This consisted of correlation analysis, multilinear regression model, analysis of variance (ANOVA) was used to determine the significance of the multilinear regression model

A $t$ - test was applied to establish the statistical significance of the relevant independent variable

This enabled the analysis of the dependent variable and the independent variables. The analysed data was then presented in figures, tables and cross tabulation tables, pie charts and bar graphs. While the inferential statistics were in form of tables.

This publication was synthesized based on the research model presented as follows 


\section{Operationalisation of Study Variables}

\section{Table 6.1 Operationalisation of Study variables}

\begin{tabular}{|c|c|}
\hline Variable & Key Indicators \\
\hline \multirow[t]{9}{*}{$\begin{array}{l}\text { Dependent Variable (Y) } \\
\text { Participation in Agriculture }\end{array}$} & $\begin{array}{l}\text { The County Government plays a significant role in influencing Youth } \\
\text { participation in Agriculture }\end{array}$ \\
\hline & $\begin{array}{l}\text { Agricultural Training Institutions in my County have adequate } \\
\text { facilities for training the Youth in Agriculture }\end{array}$ \\
\hline & $\begin{array}{l}\text { In my County, cost Agricultural inputs are subsidized for the Youth } \\
\text { who participate in Agriculture }\end{array}$ \\
\hline & $\begin{array}{l}\text { My County government has Agricultural initiatives that enable } \\
\text { Youth participation in Agriculture }\end{array}$ \\
\hline & $\begin{array}{l}\text { The County Government cushions the Youth who participate in } \\
\text { Agriculture against unforeseen losses (drought, locusts, flooding, } \\
\text { pandemic) }\end{array}$ \\
\hline & $\begin{array}{l}\text { The cost of undertaking a course in Agriculture is affordable for the } \\
\text { Youth }\end{array}$ \\
\hline & $\begin{array}{l}\text { The County Government has constructed market places for the } \\
\text { Youth to sell their farm products }\end{array}$ \\
\hline & $\begin{array}{l}\text { The County Government has provided roads that facilitate } \\
\text { transportation of farm products to the market }\end{array}$ \\
\hline & $\begin{array}{l}\text { The County Government has created an enabling environment that } \\
\text { facilitates the Youth to leverage on the use modern technology on } \\
\text { Agriculture }\end{array}$ \\
\hline \multirow{9}{*}{$\begin{array}{l}\text { Variable } \\
\text { Independent Variable (X) } \\
\text { Agricultural Policies }\end{array}$} & Key Indicators \\
\hline & $\begin{array}{l}\text { My County Government has active Policies governing Youth } \\
\text { participation }\end{array}$ \\
\hline & $\begin{array}{l}\text { There are pricing policies that are specifically allocated for the Youth } \\
\text { who participate in Agricultural activities in my County }\end{array}$ \\
\hline & $\begin{array}{l}\text { There are policies that safeguard the Youth from external } \\
\text { competition }\end{array}$ \\
\hline & $\begin{array}{l}\text { There are Agricultural Cooperatives in my County that accept } \\
\text { Agricultural produce from the Youth and sell them on their behalf }\end{array}$ \\
\hline & $\begin{array}{l}\text { The Youth in my County who participate in Agriculture are aware of } \\
\text { the Enable Youth Program sponsored by African Development Bank }\end{array}$ \\
\hline & $\begin{array}{l}\text { The Youth who participate in Agricultural activities are not } \\
\text { cushioned against unforeseen losses (Drought, floods, Locust, } \\
\text { Pandemic) }\end{array}$ \\
\hline & $\begin{array}{l}\text { The County Government has policies on providing the Youth with } \\
\text { subsidized costs for Agricultural inputs (seeds, fertilizer, farm tools } \\
\text { and equipment) }\end{array}$ \\
\hline & $\begin{array}{l}\text { The County Government has a policy on providing Youth who } \\
\text { complete Agricultural training with support to start Agricultural } \\
\text { activities }\end{array}$ \\
\hline
\end{tabular}

(Source: Authors, 2020)

Interpretation of the Coefficients with Respect to the Study Variables

$\mathrm{HO} \mathrm{O}_{\mathrm{i}}: \beta_{\mathrm{i}}=0$ versus $\mathrm{HO} \mathrm{O}_{\mathrm{i}}: \beta_{\mathrm{i}} \neq 0(\mathrm{i}=1,2,3)$ 
If the null hypothesis is rejected then the independent variable $\mathbf{X}_{i}$ has statistically significant influence on $\mathbf{Y}$, otherwise if we fail to reject the null hypothesis then the independent variable $\mathbf{X}_{\boldsymbol{i}}$ has a statistically insignificant influence on $\mathbf{Y}$.

\section{Research Findings}

Under this section, a summary of the study findings are recorded. The Respondent response rates, demography, descriptive analysis of staudy variables using proportions and concludes with inferential statistics of the study variables using the ANOVA, $t$ - test and Multiple linear regression model.

\section{Response Rate}

Study had targeted three hundred and eighty five (385) respondents from the eligible study population. Response was collected from two hundred and fifty (250) of these. On cleaning the data one hundred and ninety four (194) remained as shown in Table 7.1

Table 7.1 : Response rate

\begin{tabular}{lllll}
\hline & $\begin{array}{l}\text { Administered } \\
\text { Questionnaires }\end{array}$ & $\begin{array}{l}\text { Returned } \\
\text { Questionnaires }\end{array}$ & $\begin{array}{l}\text { After cleaning } \\
\text { Questionnaires }\end{array}$ & $\begin{array}{l}\text { Percentage } \\
\text { remaining }\end{array}$ \\
\hline Responses & 385 & 250 & 194 & $50 \%$ \\
\hline
\end{tabular}

(source: Author, 2020)

\section{Respondent County}

From Table 7.2 six per cent (6\%) were from Kitui County, twenty two percent (22\%) from Tharaka Nithi County, thirteen percent (13\%) from Kirinyaga County, twelve percent (12\%) from Isiolo County, twenty one percent (21\%) from Nyeri County, sixteen percent (16\%) from Embu County and ten percent (10\%) from Murang'a County

Table 7.2 Respondent County

\begin{tabular}{lll}
\hline County & Frequency & $\%$ \\
\hline Kitui & 11 & 6 \\
Tharaka Nithi & 43 & 22 \\
Kirinyaga & 25 & 13 \\
Isiolo & 23 & 12 \\
Nyeri & 42 & 21 \\
Embu & 31 & 16 \\
Murang'a & 19 & 10 \\
\hline & 194 & 100 \\
\hline
\end{tabular}

(source: SPSS Survey Data Output, 2020)

\section{Respondent Age}

From the figure 7.1 , thirty percent (30\%) were aged between $18-24$, forty percent (40\%) were aged between $25-29$ and thirty percent (30\%) were aged between $30-35$ 


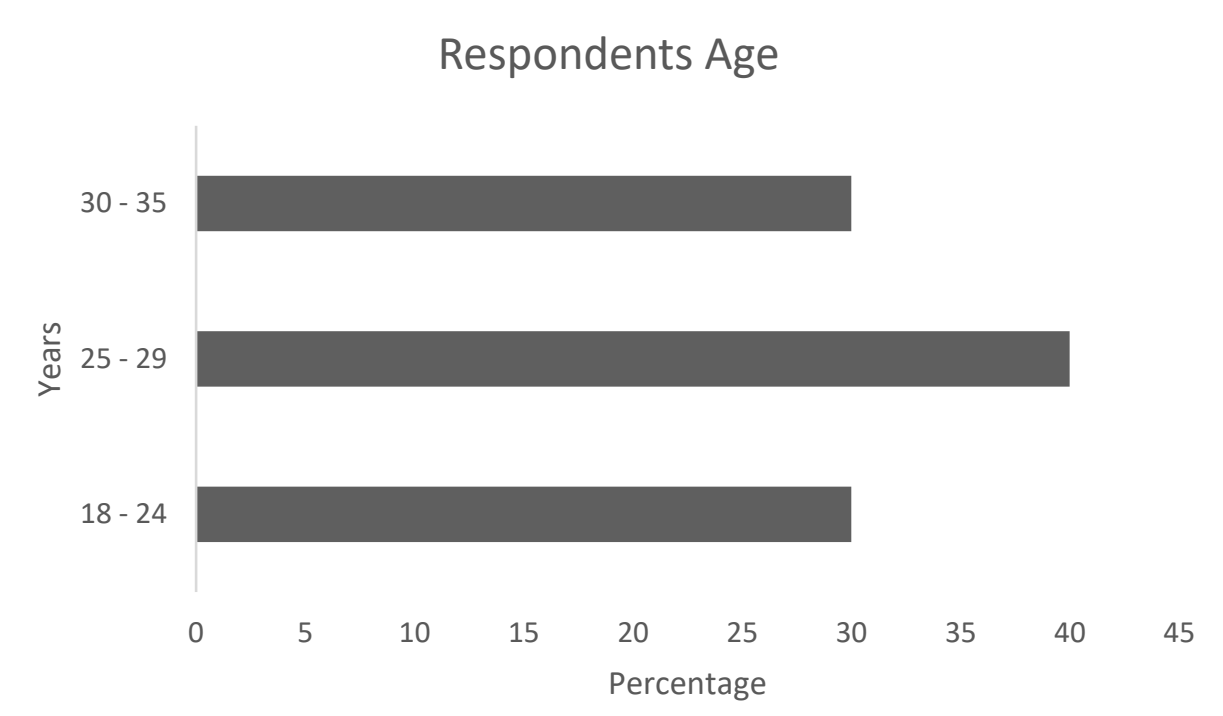

Figure 7.1 Respondents Age

(Source Excel Data output 2020)

\section{Respondents Level of Education}

From table 7.3 six percent (6\%) had a post graduate qualification in Agriculture, twenty eight percent $(28 \%)$ had a degree qualification, twenty five percent $(25 \%)$ have a diploma qualification, twenty six percent have a certificate qualification and fifteen percent $(15 \%)$ have no educational qualification

Table 7.3 Respondents Level of Educational Qualification

\begin{tabular}{ll}
\hline Level of Education & Percentage (\%) \\
\hline Post Graduate & 6 \\
Degree & 28 \\
Diploma & 25 \\
Certificate & 26 \\
None & 15 \\
\hline \multicolumn{2}{c}{ (Source: SPSS Survey Data output) }
\end{tabular}

\section{Respondents experience in Agriculture calibrated in Years}

From Figure 7.2, fifty two percent (52\%) of the respondents Agricultural experience is between $1-5$ years, twenty nine percent $(29 \%)$ had $6-10$ years, fourteen percent (14\%) had $11-15$ years, while only five percent (5\%) had no experience at all. 


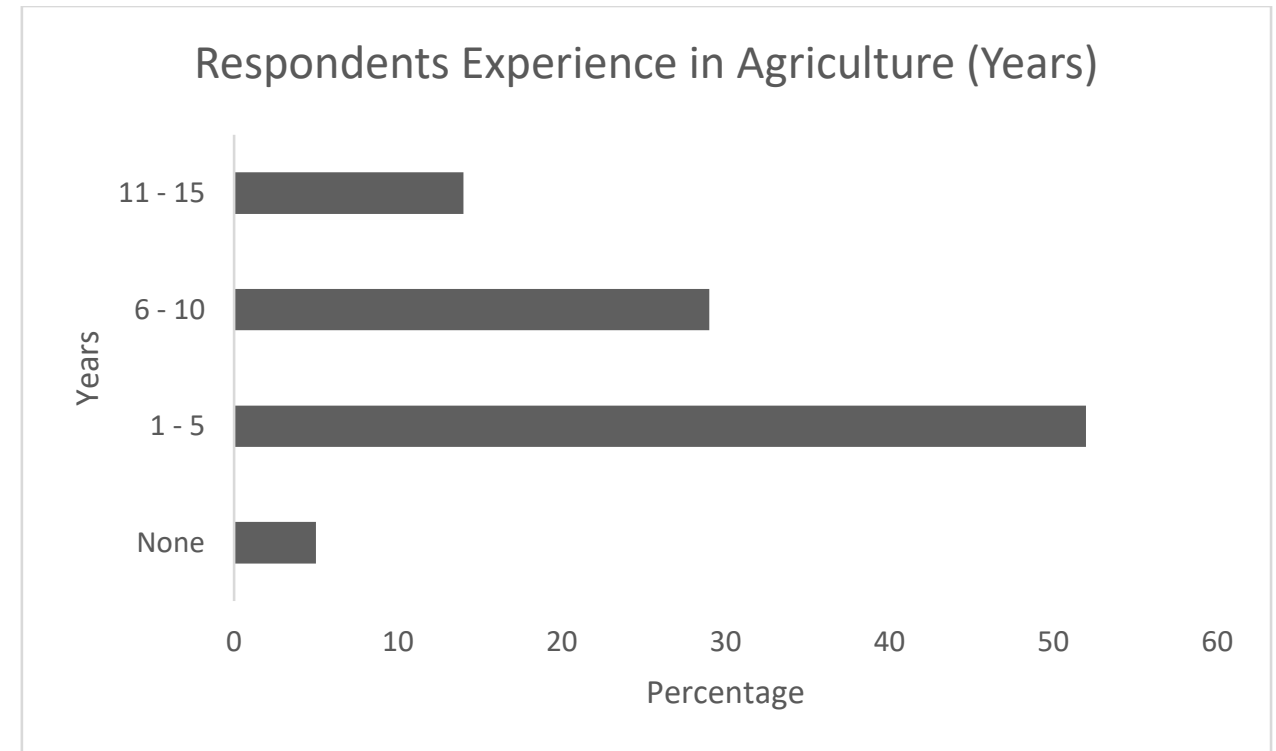

Figure 7.2 Respondents Experience in Agriculture

(Source : Excell Data output 2020)

\section{Respondents Nature of Engagement in Agriculture}

From Figure 7.3 The respondents had three different levels of engagement in the Agricultural practices. Twenty five percent (25\%) of the respondents were engaged full time, sixty eight percent (68\%) of the respondents were engaged in Agriculture on a part time basis while seven percent (7\%) did not engage in Agriculture

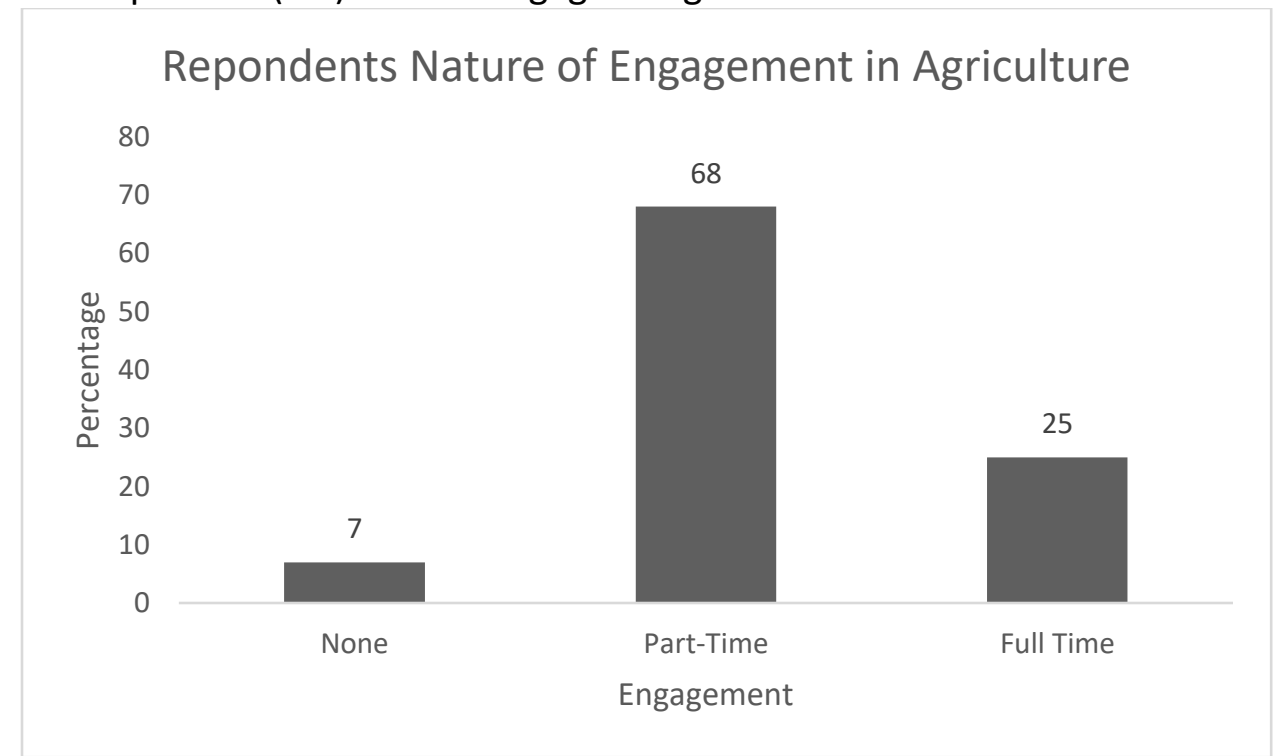

Figure 7.3 Respondents Nature of Engagement in Agriculture

(Source : Excel Data Output 2020)

\section{Respondents Locus for Farming}

The respondents practiced farming at different locales as shown in Figure 7.4. eighteen percent (18\%) of the Youth farmed on own Land, sixty four percent (64\%) of the Youth farmed on Parents land while eighteen percent (18\%) farmed on Hired land. 


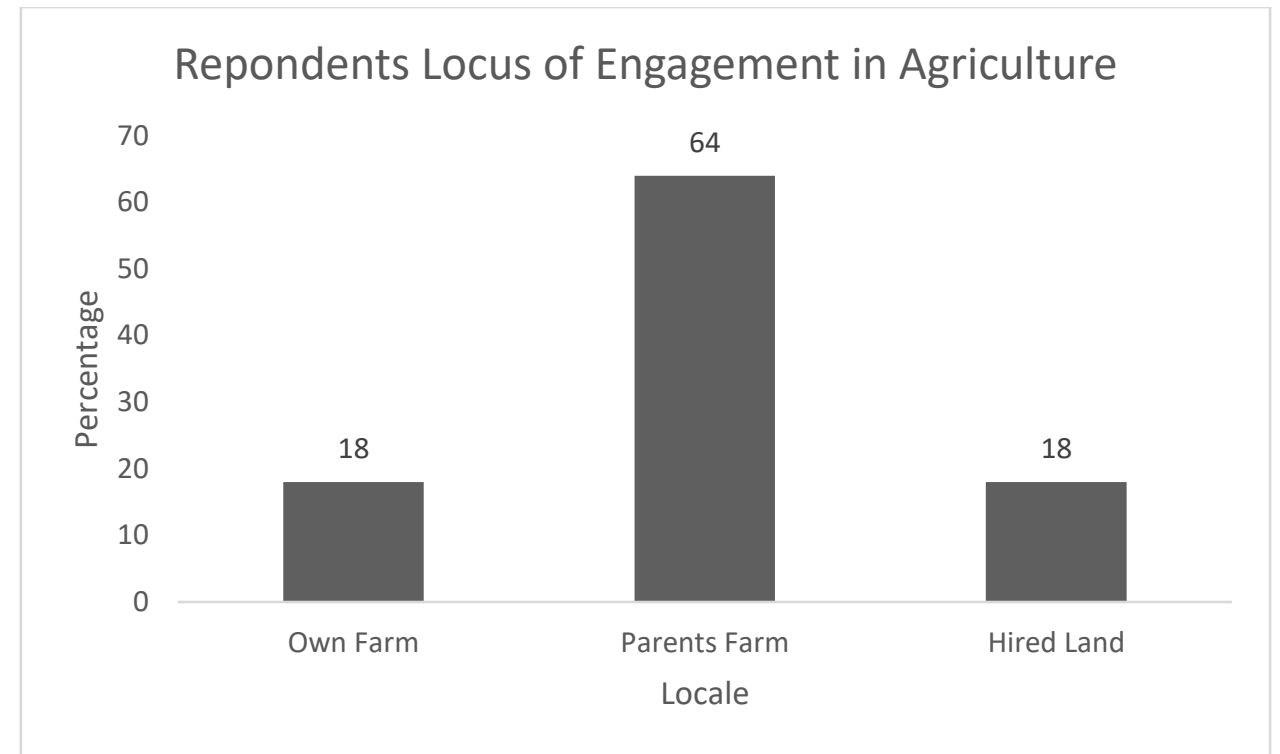

Figure 7.4 Locale of Youth Engagement in Farming

(Source : Excel Data output 2020)

\section{Respondents Scale of Farming}

The respondents practiced Agriculture to different scale. Some had large farms, others medium sized farms while some were small scale farmers. Figure 7.5 shows that one percent $(1 \%)$ of the Youth were large scale farmers, twenty five percent $(25 \%)$ were medium sized farmers while a large majority of seventy four percent $(74 \%)$ were small scale farmers.

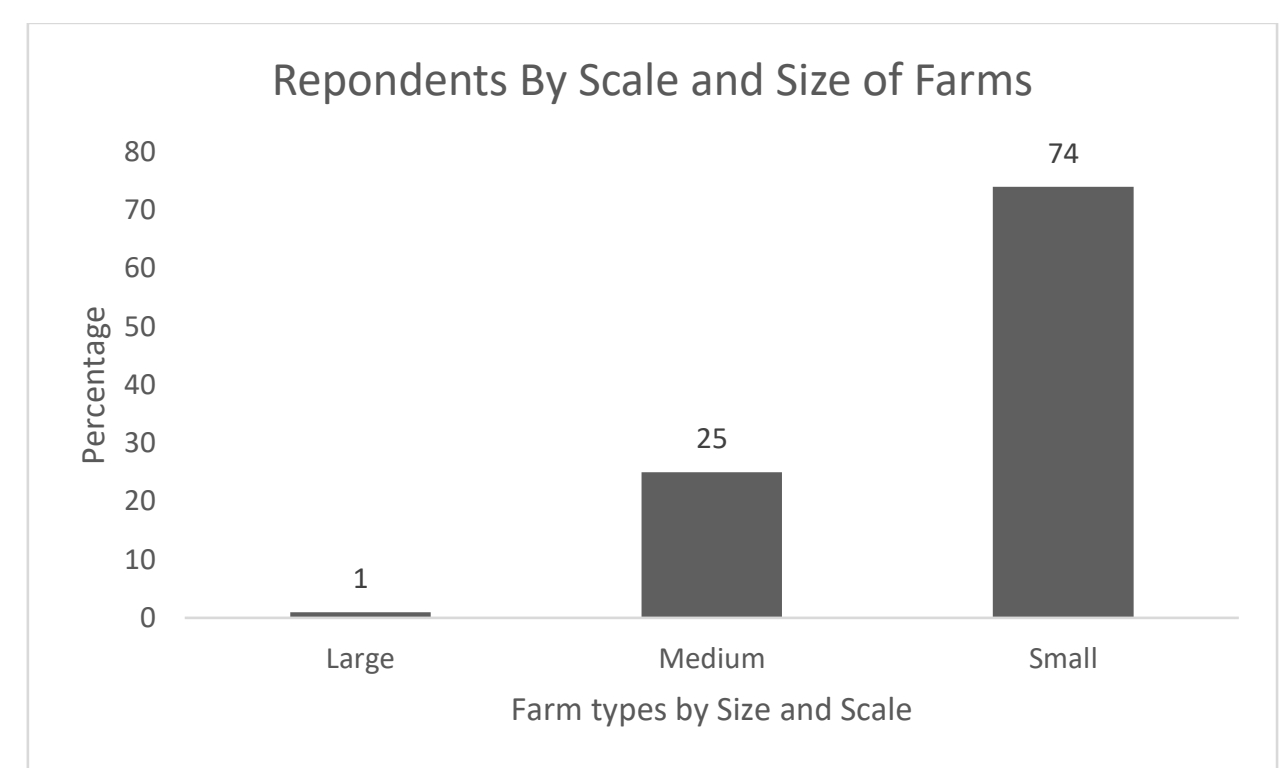

Figure 7.5 Farm Type by Size and Scale

\section{Respondents Income}

Table 7.4 shows the annual income for forming activity earned by the Respondents from their Agricultural activities provided in range from 40,000 at the lower end to 160, 000 at the higher end. In percentage terms sixty five percent (65\%) of the respondent earned below 40,000 annually from Agricultural activities, twenty one percent (21\%) earn between 40,001 80,000 , eight percent ( $8 \%$ ) earn between $80,001-120,000$, one percent (1\%) earn between $120,001-160,000$ and five percent (5\%) above 160,000 
Table 7.4 Respondent annual earnings from Agricultural activities

\begin{tabular}{ll}
\hline Annual income (Kshs) & Percentage (\%) \\
\hline Below 40,000 & 65 \\
$40,001-80,000$ & 21 \\
$80,001-120,000$ & 8 \\
$120,001-160,000$ & 1 \\
Above 160,000 & 5 \\
\hline & 100 \\
\hline
\end{tabular}

(Source : SPSS survey data output 2020)

\section{Respondents annual expenses for Agricultural activities}

Table 7.5 show the expenses the Youth incurred while undertaking Agricultural activities. Eighty one (81\%) percent of the respondents incurred less than Kshs 40,000 in expenses on Agricultural activities, fifteen percent (15\%) incurred between Kshs 40,001 - 80, 000, one percent (1\%) incurred between Kshs $80,001-120,000$ in expenses, another one percent (1\%) incurred between $120,001-160,000$ in expenses while two percent (2\%) incurred above 160,000 in expenses.

Table 7.5 Annual expenses incurred on Agricultural activities

\begin{tabular}{ll}
\hline Annual expenses in Kshs & \multicolumn{1}{c}{ Percentage (\%) } \\
\hline Below 40,000 & 81 \\
$40,001-80,000$ & 15 \\
$80,001-120,000$ & 1 \\
$120,001-160,000$ & 1 \\
Above 160,000 & 2 \\
\hline
\end{tabular}

(source : SPSS Data Survey Data output 2020)

\section{Respondents Farm type/size and Locale of Agricultural activities cross tabulation}

\section{Practice Agricultural activities in own Farm}

As per Table 7.6 of the seventy percent (70\%) who owned their own farms, seventeen percent $(17 \%)$ of these were small scale farmers. Thirty percent $(30 \%)$ of those who owned their own farms twenty two percent (22\%) were middle sized farmers.

\section{Practice Agricultural activities in Parents Farm}

Of the seventy eight percent (78\%) Youths that farmed on parents' farms, sixty seven percent $(67 \%)$ were small scale farmers. Twenty one percent $(21 \%)$ of those who farmed on parents farm, fifty four percent (54\%) were middle sized farmers. One percent (1\%) of those that farmed on parents' land were hundred percent (100\%) large scale farmers

\section{Practice Agriculture on hired farms}

Of the seventy four percent $(74 \%)$ that farmed on hired land, sixteen percent (16\%) of these did it as small scale farmers, thirty three percent of those who farmed on hired land twenty four percent were medium sized farmers. 
Table 7.6 Respondent Farm Type/Size and Locale of Farming cross tabulation

\begin{tabular}{|c|c|c|c|c|c|}
\hline \multicolumn{6}{|c|}{ Respondent Type/Size farm } \\
\hline & & Small Scale & Middle Size & Large Scale & $\%$ \\
\hline \multirow{3}{*}{$\begin{array}{l}\text { Farmer in } \\
\text { Own Farm }\end{array}$} & $\% \quad$ within & 70 & 30 & - & $100 \%$ \\
\hline & Locale & & & & \\
\hline & \% Type/Size & 17 & 22 & - & 18 \\
\hline \multirow{3}{*}{$\begin{array}{l}\text { Farmer } \\
\text { Parents' } \\
\text { Farm }\end{array}$} & $\% \quad$ within & 78 & 21 & 1 & 100 \\
\hline & Locale & & & & \\
\hline & \% Type/Size & 67 & 54 & 100 & 64 \\
\hline \multirow{6}{*}{$\begin{array}{l}\text { Farmer in } \\
\text { Hired } \\
\text { Farm/Land }\end{array}$} & $\% \quad$ within & 67 & 33 & - & 100 \\
\hline & Locale & & & & \\
\hline & \% Type/Size & 16 & 24 & - & 18 \\
\hline & $\% \quad$ within & 74 & 25 & 1 & 100 \\
\hline & Locale & & & & \\
\hline & \% Type/Size & 100 & 100 & 100 & 100 \\
\hline
\end{tabular}

(Source : SPSS Data Output, 2020)

\section{Respondents Level of Education and Type/Size of Farm Cross tabulation Post Graduate}

From Table 7.7 of the eighty two percent (82\%) that had post graduate level of education, six percent $(6 \%)$ were small scale farmers; while eighteen percent $(18 \%)$ with post graduate education four percent (4\%) of them had middle sized farms.

\section{Degree}

Of the seventy four percent (74\%) who had a degree, twenty eight percent (28\%) were small scale farmers; while of the twenty six percent $(26 \%)$ who had a degree, thirty percent $(30 \%)$ had middle sized farms.

\section{Diploma}

Of the seventy five percent (75\%) who had a diploma qualification, twenty five percent (25\%) were small scale farmers, twenty four percent (24\%) of diploma holders, twenty three percent (23\%) had middle sized farms and one percent (1\%) of the Diploma holders were hundred percent $(100 \%)$ large scale farms

\section{Certificate}

Of the eighty percent $(80 \%)$ who had certificate qualification, twenty seven percent $(27 \%)$ were small scale farmers, twenty percent $(20 \%)$ with certificate qualification, twenty two percent (22\%) had middle sized farms

\section{No Educational Qualification}

Of the sixty seven percent (67\%) of those with no educational qualification, fourteen percent $(14 \%)$ were small scale farmers, thirty three percent $(33 \%)$ of those with no educational qualification twenty one percent $(21 \%)$ had middle sized farms 
Table 7.7 Respondent level of Education and Type/Size of farm Cross tabulation Respondent Type/Size farm

\begin{tabular}{|c|c|c|c|c|c|}
\hline & & Small Scale & Middle Size & Large Scale & $\%$ \\
\hline Post & $\% \quad$ within & 82 & 18 & - & $100 \%$ \\
\hline \multirow[t]{2}{*}{ Graduate } & Level Edu & & & & \\
\hline & \% Type/Size & 6 & 4 & - & 6 \\
\hline \multirow[t]{3}{*}{ Degree } & $\% \quad$ within & 74 & 26 & - & 100 \\
\hline & Level Edu & & & & \\
\hline & \% Type/Size & 28 & 30 & - & 28 \\
\hline \multirow[t]{3}{*}{ Diploma } & $\% \quad$ within & 75 & 24 & 1 & 100 \\
\hline & Level Edu & & & & \\
\hline & \% Type/Size & 25 & 23 & 100 & 25 \\
\hline \multirow[t]{3}{*}{ Certificate } & $\% \quad$ within & 80 & 20 & - & 100 \\
\hline & Level Edu & & & & \\
\hline & \% Type/Size & 27 & 22 & - & 26 \\
\hline \multirow[t]{6}{*}{ No Education } & $\% \quad$ within & 67 & 33 & - & 100 \\
\hline & Level Edu & & & & \\
\hline & \% Type/Size & 14 & 21 & - & 15 \\
\hline & $\% \quad$ within & 74 & 25 & 1 & 100 \\
\hline & Level Edu & & & & \\
\hline & \% Type/Size & 100 & 100 & 100 & 100 \\
\hline
\end{tabular}

(Source : SPSS Survey Data, 2020)

Respondents annual income and respondents annual expenses cross tabulation Annual Income below 40,000

From Figure 7.6 ninety one percent (91\%) of the respondents whose annual income was below Kshs 40,000 , seventy five percent (75\%) incurred annually in expenses. Eight percent $(8 \%)$ of the respondents whose annual income is below Ksh 40,000 , thirty six percent $(36 \%)$ incurred annually in expenses between Ksh 40,000 and 80,000.

One percent (1\%) of the respondent whose annual income was below Ksh 40,000, thirty three percent (33\%) incurred annual expenses that were between Ksh 80,001 and 120,000

\section{Annual Income between 40,001 and 80,000}

Seventy seven percent (77\%) of the respondents whose annual income was between Ksh 40,001 and 80,000, twenty percent (20\%) incurred expenses that were below Ksh 40,000.

Twenty percent (20\%) of the respondents whose annual income was between Ksh 40,001 and 80,000 , twenty nine percent (29\%) incurred expenses between Ksh 40,001 and 80,000

Three percent (3\%) of the respondent whose annual income was between 40,001 and 80,000 Ksh 160,001 only twenty percent (20\%) incurred annual expenses that were above 160,000

\section{Annual income between 80,001 and 120,000}

Forty seven percent (47\%) of the respondents whose annual income was between Ksh 80,001 and 120,000 , five percent (5\%) incurred expenses that were below Ksh 40,000

Forty seven percent (47\%) of the respondents whose annual income was between 80,001 and 120,000 , twenty five percent (25\%) incurred annual expenses that were between Ksh 40,001 and 80,000 . 
Six percent (6\%) of the respondent whose annual income was between Ksh 80,001 and 120,000 , thirty three percent (33\%) incurred an annual expenses between Ksh 120,001 and 160,000

\section{Annual income between 120,001 and 160,000}

Fifty percent (50\%) of the respondents whose annual income was between Ksh 120,001 and 160,000 , four percent (4\%) incurred annual expenses that were between Ksh 40,001 and 80,000 , the remaining fifty percent $(50 \%)$ incurred expenses that were above Ksh 160,000

\section{Annual income above Ksh 160,001}

Twenty two percent (22\%) of the respondents whose income was above Ksh 160,000, seven percent (7\%) incurred expenses between Ksh 40,001 and 80,000

Twenty two percent (22\%) of the respondents whose annual income was above Ksh 160,000, sixty seven percent (67\%) incurred expenses between Ksh 80,001 and 120,000

Twenty two percent (22\%) of the respondents whose annual income was above Ksh 160,000, sixty seven percent (67\%) incurred expenses between Ksh 120,001 and 160, 000

Thirty seven percent (37\%) of the respondents whose annual income was above Ksh 160, 000, sixty percent (60\%) incurred expenses above Ksh 160,000

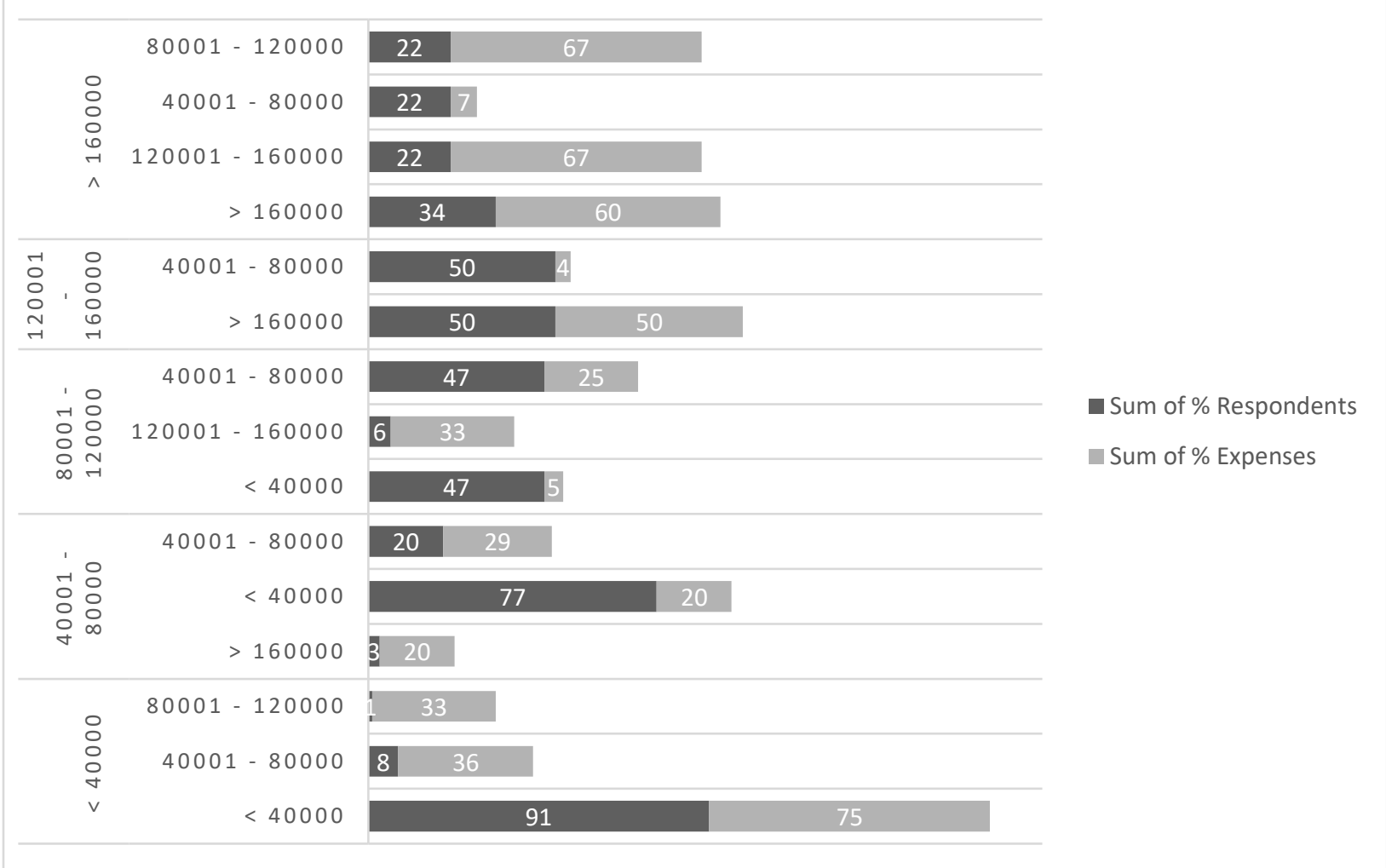

Figure 7.6 Respondent annual Income and Annual expenses

(Source: Excel Data Output, 2020)

\section{Suggest other means in which county governments may use to encourage Youth Participation in Agriculture}

From the table Seventy-one percent (71\%) of the Respondents recommended provision of capital, subsidies and incentives to encourage the Youth Nine percent (9\%) suggested provision of market opportunity to sell produce Four percent (4\%) suggested provision of affordable farming inputs 
One percent (1\%) suggested provision of infrastructure including markets

Table 7.8 Suggestions on encouraging Youth to Participate in Agriculture

Suggestions

Percentage

(\%)

1. Provide : Capital, subsidiaries \& incentives 71

2. Provide extension services, sensitization and 15 awareness

3. Provide market to sell farm produce 9

4. Provide affordable farm inputs 4

5. Sufficient infrastructure market place 2

100

(source : SPSS Data, 2020)

Findings on the Objective to establish the Influence of Agricultural Policies on Youth Participation

From the Data Influence of Agricultural Policies on Youth Participation

Only twenty three percent (23\%) of the Respondents with a mean $M=2.61$ agreed that the County Governments in their respective Counties had active policies

Only eighteen percent (18\%) of the respondents with a mean $M=2.42$ agreed that the pricing policies for agricultural produce favor Youth participation in Agricultural activities

Only thirteen percent (13\%) of the respondents with a mean $M=2.23$ agreed that the policies put in place by the County governments to safeguard the Youth from external competition Just twenty eight percent (28\%) of the respondents with a mean $M=2.61$ agreed that within the county, there are agricultural cooperatives that accept produce from the Youth and sell them on their behalf

Only fourteen percent (14\%) of the Youth in the County I reside in at a mean $M=2.31$ are aware of the Enable Youth Program sponsored by African Development Bank (ADB)

A significant figure of forty six percent $(46 \%)$ at a mean $M=3.17$ agreed that the Youth who participate in Agricultural activities are not cushioned against unforeseen losses attributed to drought, locust or floods etc

Just thirty one percent (31\%) with a mean $M=2.63$ of the respondents agree that the County government have policies on subsidizing the Youths costs on agricultural inputs (seeds, fertilizer, farm tools and equipment)

Only twenty two percent (22\%) of the respondents with a mean $\mathrm{M}=2.43$ of the respondents agreed that the County government have a policy of providing Youth who complete Agricultural training with support to start Agricultural activities

\section{Other suggestions of improving Youth participation in Agriculture through Agricultural policies}

From the data of table 7.9 five percent $(5 \%)$ suggested that the existing policies be implemented

Twenty three percent (23\%) of the respondents opined that the Youth get involved during the public participation before the policies are formulated

Five percent $(5 \%)$ felt that it was important that the youth be sensitized on the proposed Agricultural policies 
Thirty one percent (31\%) of the respondents felt that the policies to be pursued need to be those that promote local market for the Agricultural produce and discourage imports Five percent $(5 \%)$ of the respondents suggested that the existing policies be reviewed Twenty eight percent (28\%) of the respondent proposed that quality policies promoting Youth participation in Agriculture be formulated

Table 7.9 Suggestions on What needs to be done to Improve Youth Participation in Agriculture

\begin{tabular}{lll}
\hline Suggestions & \multicolumn{1}{c}{$\begin{array}{c}\text { Percentage } \\
\text { (\%) }\end{array}$} \\
\hline 1. Implementation of existing policies & 6 \\
2. Youth participation (public) before policy \\
$\quad$ formulation
\end{tabular}

(Source : SPSS Data, 2020)

Inferential Statistics on how Agricultural Policies influence the Youth Participation in Agriculture

Table 8: Model Summary

\begin{tabular}{lllll}
\hline Model & R & R Square & Adjusted R Square & Std. Error of the Estimate \\
\hline 1 & $.587^{\text {a }}$ & .344 & .341 & .54156 \\
\hline
\end{tabular}

a. Predictors: (Constant), Agricultural Policies

b. Dependent Variable: Participation in Agriculture

(Source: SPSS Survey Data Output, 2020)

From Table 9 the simple linear regression model, there was statistically significant $(F(1,191)$ $=99.736) p<.05$ in predicting the Participation of the Youth in Agriculture with a goodness of fit of $34.1 \%$ (Adjusted R Square $=.341$ ) as shown in Table 8.

Table 9: ANOVAa for the Study Variables on the Youth Participation in Agriculture

\begin{tabular}{llllll} 
Model & Sum of Squares & df & Mean Square & F & Sig. \\
\hline \multicolumn{1}{c}{ Regression } & 29.251 & 1 & 29.251 & 99.736 & $.000^{b}$ \\
1 Residual & 55.724 & 190 & .293 & & \\
Total & 84.975 & 191 & & & \\
\hline
\end{tabular}

a. Dependent Variable: Participation in Agriculture

b. Predictors: (Constant), Agricultural Policies

(Source: SPSS Survey Data Output, 2020) 
This shows that the coefficient of determination of $34.1 \%$ was the variation in the Youth Participation in Agriculture $(Y)$ that was explained by the study variable Agricultural Policies $\mathbf{X}_{1}$.

The fitted simple regression model of this relationship was:

$\mathrm{Y}=4.673-0.500 \mathrm{X}_{1}$

From Table 10 the findings showed that Agricultural Policies $\left(\mathbf{X}_{\mathbf{1}}\right)$ did have a statistically significant influence on the Participation of the Youth in Agriculture, since the findings were statistically significant $\left(\boldsymbol{B}_{1}=-0.500, t=-9.987 ., p<.05\right)$ as shown in Table 10.

For one unit increase in Agricultural Policies, the Youth Participation in Agriculture increased by 0.697 units.

For one unit increase in Agricultural Policies, the Participation of the Youth in Agriculture increased by 0.657 units.

Hence, we Reject The null Hypothesis that:

$\mathrm{H}_{03}$ : Agricultural policies do not have a statistically significant influence on the Participation of the Youth in Agriculture.

Table 10: Coefficients ${ }^{a}$ of the Study Variables on the Participation of the Youth in Agriculture

\begin{tabular}{|c|c|c|c|c|c|c|c|}
\hline \multirow{2}{*}{ Model } & \multicolumn{2}{|c|}{$\begin{array}{l}\text { Unstandardized } \\
\text { Coefficients }\end{array}$} & \multirow{2}{*}{$\begin{array}{l}\text { Standardized } \\
\text { Coefficients } \\
\text { Beta }\end{array}$} & \multirow[t]{2}{*}{$\mathbf{t}$} & \multirow[t]{2}{*}{ Sig. } & \multicolumn{2}{|c|}{$\begin{array}{l}95.0 \% \text { Confidence } \\
\text { Interval for B }\end{array}$} \\
\hline & B & $\begin{array}{l}\text { Standard } \\
\text { Error }\end{array}$ & & & & $\begin{array}{l}\text { Lower } \\
\text { Bound }\end{array}$ & $\begin{array}{l}\text { Upper } \\
\text { Bound }\end{array}$ \\
\hline (Constant) & 4.673 & .134 & & 34.982 & .000 & 4.409 & 4.936 \\
\hline $\begin{array}{r}1 \text { Agricultural } \\
\text { Policies }\left(X_{1}\right)\end{array}$ & -.500 & .050 & -.587 & -9.987 & .000 & -.599 & -.401 \\
\hline
\end{tabular}

a. Dependent Variable: Participation in Agriculture

(Source: SPSS Survey Data Output, 2020)

\section{Discussion of the Findings}

An interesting pattern was identified on the matter of age distribution of the respondents. As shown on Table 7.1 the age groups $18-24$ and $30-35$ were thirty percent (30\%) each, while 25 - 29 group was forty (40\%) percent. Since the gender of the respondents was overwhelmingly male, the Researchers deduced that the younger age set was either school/college going while the older leave home for prospects elsewhere since they would conventionally be expected to have started families and fending for them. Thus a classic application of the Push - Pull theory. Therefore, for impact, interventions need to come in early especially with the younger age set to buttress interest of the respondents, equip them with skills specifically entrepreneurial skills that would help them manage risks thus apt for a keen government bureaucrat whether at the County or National Government to make use of the entrepreneurial cognition theory as a tool in the intervention provided in resource terms such as tacit, technical knowledge, information and point out to available opportunities to the Youth.

Secondly for those youth still in Schools and Colleges, mechanism such as the Young Farmers clubs and in Kenya the 4K clubs can be revived. This is mainly a push mechanism of then Push 
and pull theory to nudge the youths towards orienting, familiarizing and liking agriculture and agricultural practices. They can be encouraged to rear and breed rabbits, pigeons and even dogs as a hobby, these would then facilitate the young ones to transit into farmers and have a positive attitude to farming as a career, as well as grow social capital "people of like mind". The entrepreneurial theory would facilitate the government at different level encourage the Youth to form and manage aggregators like Cooperatives, Youth groups that would allow them benefits of economies of scale and scope and be attractive to support mechanisms and structures like that provided by entities such as the African Development Bank (ADB) through the enable Youth Program, the available funds by both the National and County government. These aggregators will go a long way in redressing the pricing policy disadvantage that was shown among the policies that have a disempowering effect on the motivation of youth to engage in Agricultural activities.

The demonstrated widely available trained and educated Youth as indicated by Table 7.3 where eighty five percent (85\%) of the respondents are shown to have at a minimum a certificate in education as well as the fact that as shown by Table 7.2 that almost ninety five percent (95\%) have between $1-15$ years experience in farming or agricultural activities, this is a pull factor for the government at whatever level. These demonstrate a pool of available and amenable Resource to introduce start ups in Agriculture depending with the respective Agro-ecological zones where suitable practices can be introduced and nurtured to enhance productivity. Suitably designed interventions generated through consensus that has on board all key stakeholders including parents as the data shows that a large chunk of the youth practice agriculture on land that belongs to their parents. Making use of the entrepreneurial approach will allow for higher productivity of high value agricultural output that can allow more youth to venture into the wide field of commercial agriculture including having the capacity to hire farms and enhance better or higher income and lower cost. The various Youth initiatives and programs need to come of age for instance Many of the challenges the youth face in terms of finance and advice can be apt programs for the Youth Development funds set up for the Youth and that the National Youth Councils stop just being talking shops and generate solutions for the young people, by the young people with sufficient hand holding and mentoring from the Youth Enterprise development program of NEPAD and other continent wide mechanism for their impact to be felt by the Youth

\section{Conclusions}

The study made the following conclusions that was based the objective of the study, as follows:

\section{Specific Objective: To establish the influence of Agricultural Policies on Youth Participation in Agriculture}

The Agricultural Policies determinant was also found to influence the Youth Participation in Agriculture. When the Youth are not welcome or offered a seat at the table, when matters involving them are not part of the agenda, then their participation is minimal. This was evidenced from some of the key indicators such: The few policies we reviewed, for instance the National Rice Development Policy; the Root and Tuber Crop strategy and the Tea subsector policy that had the youth component more of as an afterthought as well as the County Governments as having no active policies governing Youth participation in Agriculture and that the County Governments have no policy on providing the Youth with subsidized costs for Agricultural inputs (i.e. seeds, fertilizer, farm tools and equipment). receding back to the 
theoretical framework, we see that the government be it at the National or County level along with her partners has an opportunity to apply the entrepreneurial cognitive theory in her intervention as seen in the discussions of the findings above. While these challenges are complex and interwoven, a number of key conclusions can be drawn from this study: ensuring that youth have access to the right information is crucial. This will create a platform for aggregations (Cooperatives, Youth Groups etc) that would facilitate economies of scale and scope; integrated training approaches are required so that youth may respond to the needs of a more modern agricultural sector, the pull factor that would provide the platform is the fact that the Youths have the basics such as education and the exposure through the demonstrated experience in the practice of Agriculture; modern information and communications technologies offer great potential; there is a distinct need to organize and bring youth together to improve their capacities for collective action; youth specific projects and programs can be effective in providing youth with the extra push needed to enter the agricultural sector; and a coherent and integrated response is needed from policymakers and development practitioners alike to ensure that the core challenges faced by youth are effectively addressed. The findings showed that despite the expenses incurred annually outweighing the incomes a majority of the Youth still engaged in farming. A Push factor is the lack of clear or nascent opportunity in the agricultural sector as well as sociocultural pressures are among significant drivers for Youth seeking alternative livelihoods. Two additional drivers of migration to other sectors are the lack of land tenure security, and a Youthful population (FAO, 2014). This is in concurrence with (Bello, Allahjabou, \& Baig, 2015) who carried out a study in Sudan on Attitudes of Rural Youth on Agriculture as a Main Occupation found that the high cost of Agricultural production being the main reason behind the Youth not participating in Agriculture. These findings affirm the Pull and Push theory, that a number of the pull and push factors influence the Participation of the Youth in Agricultural activities. Likewise, from the study a majority of the Youth were part-time farmers and were small scale farmers in parents' land.

This is in tandem with (Tafere \& Woldehanna, 2012) from their study in Ethiopia, observed that individual and household characteristics have strong link with aspirations of rural youth particularly on Agricultural aspirations. Further, they pointed out the strong influence of family or household on children aspiration levels.

This is in agreement with a study by (Bahaman, Jeffrey, Azril, \& Jegak, 2010) who found that urban and rural Youth have similar level of acceptance, attitude, and knowledge towards contract farming. Similarly, this agrees with studies suggesting that young people have very diverse attitudes towards farming and rural areas (Berckmoes \& White, 2016). Similarly, (Ampadu, 2012) carried out interviews in Ghana, with young people who suggested that some want to farm, and that 'self-satisfaction, social approval and not necessarily monetary' returns are important, even though the need to make money in order to survive is recognized. These findings confirm an earlier study where it was found that minority of the youth had a positive attitude towards Agriculture. This study, however, contradicts the findings from some a study by (Norsida, 2012) which indicate that there is a negative attitude among youth towards Agriculture (Udemezue, 2019).

\section{Recommendations}

The Researchers made the following recommendations that was based on the objective of the study, as follows: 


\section{Specific Objective: To establish the influence of Agricultural Policies on Youth Participation in Agriculture.}

1. From the findings, the study recommends that the National Government and County Governments- Ministry of Agriculture Livestock and Fisheries of Kitui, Tharaka Nithi, Kirinyaga, Isiolo, Nyeri, Embu and Murang'a, together with other agencies such as Kenya School of Agriculture and Kenya School of Government and Development Partners should devise concrete intervention policies and strategies on realistic and practical ways of instilling an Agricultural oriented Youth through a three pronged approach, namely:

a. on income related policies (encouraging the Youth to take a more entrepreneurial approach to the practice of Agriculture),

b. price related policies (encourage the Youth to form aggregates that would facilitate economies of scale and scope) and

c. Supply related policies (seeking ways and means of lowering the costs, while enhancing the efficiency and effectiveness of supply and value chains). Aggregations too will play a significant role here for they allow operations at scale thus lowering the cost per unit

2. The National Government and County Governments should:

I. Facilitate Public participation of the Youth in formulation of policies (Policy dialogues).

II. Ensure that the Ministries and Departments of Agriculture and Education coordinate when developing the Syllabus for training in agriculture as well as foster and promote Agriculture clubs

III. Formulate policies that promote ready market for Agricultural goods.

IV. Reviewing existing Agricultural policies, including considering the Youth element has a level of prominence and Implementation of existing policies.

V. Each county to prioritize the Youth in Agriculture agenda in their CIDPs, as an insurance policy in view of the aging farming community.

3. Youth Policies and sectoral programs at whatever level of government have to have a prominent place for Agriculture especially as an enterprise and a career option as a thematic area.

\section{References}

Agricultural Sector Coordination Unit (ASCU). (2011). National Food and Nutrition Security Policy. Nairobi: Government of Kenya.

Ampadu, R. A. (2012). "The Land of Our Birth" Rural Youths Aspirations and Career Choices in Farming. Young People, Farming and Food Conference. Accra: Young Lives UK.

Bahaman, A. S., Jeffrey, L. D., Azril, H. M., \& Jegak, U. (2010). Acceptance, Attitude and Knowledge towards Agriculture Economic activity between Rural and Urban Youth :. Journal of Applied Sciences, 2310-2315.

Bello, A. S., Allahjabou, H. A., \& Baig, M. B. (2015). Attitudes of Rural Youths towards Agriculture as an Occupation : A case study from Sudan. International Journal of Development and Sustainability, 415 - 424.

Berckmoes, L., \& White, B. (2016). Youth Farming and Precarity in Burindi. In Generationing Development (pp. 291-312).

FAO. (2014). The State of Food and Agriculture : Innovation in Family Farming. Rome: FAO. 
Food, Agriculture and Natural Resource Policy Analysis Network (FANRPAN). (2012). Engaging Youth in Agricultural Policy Process. Pretoria: Food, Agriculture and Natural Resource Policy Analysis Network (FANRPAN).

Gitau, A., \& Goris, Y. (2016). Youth in Agriculture Transformation : The Case of Kenya. Include Platform.

Gitau, M. (2021). home: Agro-Environment Initiative. Retrieved from Agro-Environment Initiative: http://yagrein.blogspot.com/p/home.html

Jackson, S. L. (2009). Research Methods and Statistics: A critical Thinking Approach. Belmont CA: Wadsworth.

Kabir, S. M. (2016). Basic Guidelines for Research : An intoductory approach for All Disciplines. Chittagong: Book zone Publications.

Kenya National Bureaue of Statistics. (2019). National Census and Household Survey. Nairobi: Kenya National Bureau of Statistics.

Kirkwood, J. (2009). Motivational Factors in Push-Pull Theory of Entepreneurship. Gender in Management, 346 - 364.

Land Portal Foundation. (2021). Library:Agricultural Sector Development Strategy 2010 2020. Retrieved from Land Portal: https://landportal.org/library/resources/lexfaoc140935/agricultural-sector-development-strategy-2010\%E2\%80\%932020

Liehr, P., \& Smith, M. (1999). Middle range theory:spining research and practice to create knowledge for the new millenium. Advanced Nursing Science, 81-91.

Ministry of Agriculture, Livestock and Fisheries. (2017). Agricultural Sector Development Strategy 2010 - 2020. Nairobi: Ministry of Agricluture, Livestock and Fisheries.

Ministry of Agriculture, Livestock, Fisheries and Cooperatives. (2019). National Roots and Tuber Crops Development Strategy, 2019 - 2022. Nairobi: Ministry of Agriculture, Livestock, Fisherirs and Irrigation.

Mitchel, R., Busenitz, L. W., Lant, T., McDougall-Covin, P. P., Morse, E. A., \& Smith, J. B. (2003). Toward a Theory of Entepreneural Cognition : Rethinking the People Side of Entepreneurship Research. Enterpreneurship Therory and Practice, 93 - 104.

Norsida, M. (2012). Unleashing Youth Potentials in Developing the Agricultural Sector. Pertanika Journal of Social Science and Humanities, 93-106.

Rice Promotion Programme. (2020). National Rice Development Strategy - 2 (2019 - 2030). Nairobi: Minsitry of Agriculture, Livestock, Fisheries and Cooperative - State Department of Crop Development and Agricultural Research.

Tafere, Y., \& Woldehanna, T. (2012). Rural Youths Aspiring to Occupation beyond Agriculture : Evidence from Young Lives Study in Ethiopia. Young People Farming and Food Conference. Accra: Young Lives UK.

Trigueros, R. L. (2018). Conceptual Framework, Theoretical Framework, State of Art and Referenced Framework. El Salvador: University of El Salvador.

Udemezue, J. C. (2019). Agriculture for all: Constraints for Youth Participation in Africa. Current Investigations in Agriculture and Current Research. 